the body. It is greatly to be preferred to the Murphy drip. I have employed a normal saline solution with 4 per cent. dextrose; of this from 100 to 200 c.c. are slowly introduced either between the shoulders or into the abdominal walls.

In feeding, breast-milk is indispensable. We begin food as soon as the child has fairly recovered from his anesthetic, or about four hours after operation, giving 2 teaspoonfuls of breast-milk every two hours, alternating this with 2 teaspoonfuls of boiled water. On the following day the interval is made three hours, and the milk and water are each increased to $1 / 2$ ounce. At the end of forty-eight hours, 1 ounce of breastmilk is given every three hours alternating with 1 ounce of water. By the end of a week the child is usually taking from 2 to 3 ounces of pumped breastmilk every three hours alternating with boiled water. By the tenth or twelfth day in most cases the child is put to the breast, but the amount of milk allowed is limited for the next week or two.

A teaspoonful of castor oil is administered at the end of thirty-six hours and is usually followed by free evacuation from the bowels, which in many cases have not been freely moved up to that time.

The child's bed is inclined at an angle of about 135 degrees or more, the head being raised. This posture facilitates the expulsion of gas from the stomach and greatly diminishes the chances of vomiting. The child is usually kept in this position for four or five days.

\section{CHOICE OF TREATMENT}

Whether in a given case we shall decide in favor of operation or medical treatment will then depend largely on the severity of the symptoms and the conditions under which the child is seen. To subject every infant with pyloric stenosis to so serious an operation as laparotomy for a condition in which at a low estimate 50 per cent. recover without it, seems hardly justifiable. I believe it to be a mistake to turn every case over to the surgeon as soon as the diagnosis is made, as some would have us do. On the other hand, the position taken by Hutchison, that "operation is never under any circumstances justified" in these cases is, I believe, untenable. I do not think that the physician realizes how well these patients do surgically, or that the surgeon appreciates how many of them recover when treated medically.

Given an early diagnosis, a patient in private practice under conditions which make the best medical treatment possible, operation may not in most cases be required; but in hospital practice, in cases seen late, in those with the most acute symptoms who are losing rapidly, and when circumstances do not admit of the best medical treatment, there is no question in my mind but that immediate resort to surgery offers a better chance of recovery. Again, to persist with medical treatment week after woek when forcible vomiting and marked peristalsis are either continually present or keep recurring, when the weight shows only a slight loss, seems to me to be incurring far greater risks with the child than those of operation.

The medical treatment for patients not operated on consists in careful feeding and stomach-washing. The gastric lavage should be practiced twice a day; it serves the purpose of emptying the stomach thoroughly of mucus and fermented food; the water should be used warmer than usual, that is, up to $112 \mathrm{~F}$. If it can be secured, breast-milk is the preferable food, but one not rich in fat is essential. The common practice of weaning as soon as symptoms develop is most unwise. In default of breast-milk a modified milk mixture low in fat should be employed.

With respect to quantities and intervals of feeding, cases respond differently. We have usually depended on from 1 to 3 ounces at three- or four-hour intervals, water being given in small quantities between feedings. There are seen, however, some children who seem to do better on much smaller quantities, that is, $1 / 2$ ounce every hour, especially if the food is breast-milk. In greatly prostrated patients hypodermoclysis may be used twice a day as described in the postoperative treatment. Rectal feeding is little assistance except for a very short time. The bowels are moved readily by an enema, and the rectum does not discriminate between those things which are to be retained and those which are to be expelled. At most, it is of assistance only for a day or two. Drugs I believe to be of little or no value, nor can I say more for local applications of heat over the epigastrium as advised by many.

Every case of pyloric stenosis medically treated must be very closely watched; daily weights should be taken, as these children have a way of slipping away unless the most careful observations are made.

Aspiration of the stomach to determine the degree and rate of emptying is of much assistance in deciding the frequency with which these children should be fed and the amount of food offered at one time. Its value is not appreciated.

14 West Fifty-Fifth Street.

\section{PYLORIC OBSTRUCTION IN INFANTS}

\section{A REPORT OF TWENTY-TWO PERSONAL CASES WITH OPERATION *}

WILLIAM A. DOWNES, M.D. NEW YORK

The intention of this paper is to record as accurately as possible the results in the twenty-two cases of pyloric obstruction in infants which have come under my care. In order to make the report complete, it will be necessary to detail the symptoms for which relief was sought, together with the physical signs leading to the correct diagnosis. Furthermore, the findings at operation and necropsy will be mentioned, for a clear understanding of the pathologic condition present is essential in order that those who are not familiar with the disease may draw correct conclusions. Finally, the operative procedure adopted will be discussed and a critical analysis made of the results obtained.

Of the 22 patients, 17 were males and 5 females; 18 were breast-fed entirely ; 2 part breast-fed and part bottle-fed, and 2 bottle-fed; in 14 cases the patient was the first baby; in 4 , the second; in 2 , the third, and in 2 , the fourth.

The symptoms appeared from three days to seven weeks after birth, average time three and one-half weeks. In every case vomiting was the first symptom to be noted, though in one or two instances the mothers recalled that a day or so before the vomiting began there was a loss of appetite, and in one case it had been difficult to get the baby to take its feedings

\footnotetext{
* Read before the Academy of Medicine, April 16, 1914.
} 
properly from birth. The latter observation is unusual, for as a rule these babies have nursed too freely, taking large quantities at a time. This tendency to overdistend the stomach, with its resulting spasmodic contraction, is considered by some observers as of etiologic significance. The vomiting was projectile and usually occurred shortly after each feeding; in a few cases, however, it occurred at intervals of several hours and was probably the accumulation of a number of feedings. The vomitus was frequently examined for bile, but none was found. Constipation was marked in every case. The first colon irrigation, after admission to the hospital, often brought away small amounts of fecal matter, but those given later on returned clear. The urine was scant or absent. A marked loss of weight immediately followed the onset of vomiting, and in one (Case 6), amounted to 2 pounds in one week. Depression varying in degree from moderate apathy to profound shock was present in all the cases. This condition is the danger-signal, and the first suggestion of it should serve as a warning that the time for radical measures has arrived. One of our patients (Case 10) admitted to the hospital at $6 \mathrm{p}$. m., examined by me, and the diagnosis of true stenosis concurred in, was somewhat apathetic, but seemed in fairly good condition and it was thought that the operation cottld with safety be postponed

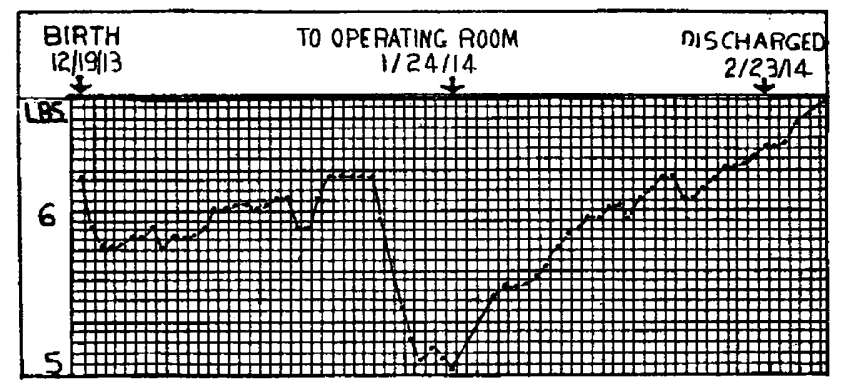

Weight-chart in Case 17, illustrating usual gain in average case after gastro-enterostomy.

until the following morning. At 6 a. m., twelve hours after admission, the child suddenly became markedly depressed. A state of profound shock supervened, and when I saw the baby at $8: 15$ a. m., the condition was practically hopeless. Hypodermoclysis and stimulation had been resorted to, with little or no improvement. With a full realization of the very slight chance offered by any method of treatment at this time, a rapid posterior gastro-enterostomy was done, but the condition was not improved, even though feeding was begun in two hours, and the child died four hours later.

With four or five exceptions the babies were emaciated, with wrinkled skins and sunken eyes. The lower abdomen was retracted and usually soft, while the epigastric region was full and prominent and all the patients presented at some time, in the region of the stomach, peristaltic waves passing from left to right. While these waves are present in all tumor cases, they may also be present in the so-called spasm cases and should not lead to the diagnosis of true stenosis without other more reliable symptoms and signs. On palpation, to the right of the median line below the costal margin, a firm movable tumor about the size of an olive was felt in each case, with the single exception of the first one, and in this instance the tumor was made out under the anesthetic before the abdcmen was opened.

Beginning with the eighth case, aspiration of the stomach was practiced as a routine measure, and each stomach was found to have from $1 / 2$ to 4 ounces' retention three hours after feeding, even though vomiting had occurred.

We did not consider it necessary or even desirable to submit the babies to Roentgen-ray examination before operation. On account of the extreme irritability of these stomachs, conclusions based on the emptying-time are liable to be misleading, and even if a small amount of bismuth passed through the pylorus, no information would be given thereby that the story of the stools and weight-chart had not already told. Such an examination might possibly be indicated in an exceptional case, but I feel that the diagnostic points already enumerated are sufficiently conclusive. Aspiration has all the advantages of the Roentgen ray in this condition and is more feasible. The average duration of symptoms before operation was performed was two weeks and one day; the longest period was eight weeks and three days, and shortest period six days.

When the abdomen was opened, a pyloric tumor varying in size from the terminal phalanx of the ringfinger to that of the thumb was found in every case. These tumors were hard, smooth, freely movable and free from adhesions. The pyloric portion of most of the stomachs was thickened and somewhat edemators, and about half of them were dilated. No other pathologic lesions or malformations were found. A typical posterior gastrojejunostomy was done in twentyone cases, and the Weber operation of partial pyloroplasty as described by Rammstedt in one case.

A passing remark as regards a few points in the technic may not be out of place. Ether should be the anesthetic used. The abdominal incision should be from $1 / 2$ to $3 / 4$ inch to the left of the median line. The reasons for this are twofold: In the first place there is so little subcutaneous tissue in these babies that there is difficulty in obtaining union in the median wound, whereas the incision through the rectus muscle heals much more readily. Many postoperative deaths have followed evisceration resulting from non-union in these cases. The second reason for placing the incision to the left of the median line is the avoidance of the round ligament of the liver. At necropsy, in one of our fatal cases, a large hemorrhage was found just where the needle used in closing the abdominal cavity had punctured this ligament.

With the exception of the first two cases, stomachclamps were not used in doing the gastro-enterostomy. There is practically no leakage from the stomach or intestine, and very little bleeding in these cases. A number of the operations were done in twenty-five minutes - longest time forty-five minutes. The partial pyloroplasty, or "nicking of the circular musclefibers," consisted in making an incision 1 inch long through the peritoneum and circular muscle-fiber down to the mucosa. The edges of the wound gaped widely and the mucous membrane immediately protrucled. No effort was made to close or cover over the incision. This simple division of the circular muscle at once relieved the obstruction, as shown by the ability to express air freely from the stomach into the duodenum. In making the incision the tumor should be held firmly between the thumb and index-finger in 
RECORD OF TWENTY-TWO OPERATIVE CASES OF PYLORIC OBSTRUCTION IN INFANTS

\begin{tabular}{|c|c|c|c|c|c|c|c|c|}
\hline \multirow{2}{*}{$\begin{array}{l}\dot{0} \\
\dot{0} \\
0 \\
0 \\
0\end{array}$} & \multirow[b]{2}{*}{$\begin{array}{l}\text { Hospital } \\
\text { Record } \\
\text { Number }\end{array}$} & \multirow[b]{2}{*}{ "ே.ّ } & \multirow[b]{2}{*}{$\begin{array}{c}\text { Age } \\
\text { Weeks }\end{array}$} & \multirow[b]{2}{*}{$\begin{array}{l}\text { Date of } \\
\text { Operation }\end{array}$} & \multirow[b]{2}{*}{ Remarks } & \multicolumn{2}{|c|}{ Weight } & \multirow[b]{2}{*}{$\begin{array}{c}\text { Final Result with Note as to When } \\
\text { Last Seen }\end{array}$} \\
\hline & & & & & & $\begin{array}{l}\text { At } \\
\text { Birth, } \\
\text { Lbs. }\end{array}$ & $\begin{array}{l}\text { At Opera- } \\
\text { tion, } \\
\text { Lbs. }\end{array}$ & \\
\hline 1 & $\begin{array}{l}\text { Babies' } \\
\text { M. H. }\end{array}$ & q & 8 & $4 / 29 / 10$ & $\begin{array}{l}\text { Vomiting began in 6th week, always } \\
\text { forcible and in large quantities. At } \\
\text { same time infant was }\end{array}$ & $81 / 2$ & 8 & $\begin{array}{l}\text { Died } 11 \text { days after operation; necropsy: } \\
\text { Wound healed perfectly; no pathologic } \\
\text { cause for death found }\end{array}$ \\
\hline 2 & $\begin{array}{l}\text { Babies' } \\
3906 \\
\text { D. B. }\end{array}$ & 8 & 6 & $7 / 30 / 10$ & $\begin{array}{l}\text { Vomiting began in 4th week; this along } \\
\text { with constipation continued till admis- } \\
\text { sion. Vomiting always forcible and } \\
\text { directly after eating. }\end{array}$ & $11(?)$ & $91 / 16$ & $\begin{array}{l}\text { Discharged Aug, 9, 1910; weight } 9 \text { 1bs., } \\
\text { 516 oz.; readmitted Aug. 13, 1910; } \\
\text { died Aug. 13, 1910; Necropsy: Gastro- } \\
\text { enterostomy perfectly healed; no adhe- } \\
\text { sions; cause of death; acute gastro- } \\
\text { enteritis; pylorus tight. }\end{array}$ \\
\hline 3 & $\begin{array}{l}\text { Babies' } \\
\text { J. S. }\end{array}$ & 3 & $23 \dagger$ & $11 / 27 / 11$ & $\begin{array}{l}\text { Vomiting began on } 11 \text { th day. One week } \\
\text { before admission constipated; no stool } \\
\text { without injection. }\end{array}$ & $?$ & $5^{21 / 32}$ & $\begin{array}{l}\text { Discharged bec. } 19,1911 \text {; weight } 6 \text { lbs., } \\
51 / 2 \text { oz; last seen Oct.; 1913; well-de- } \\
\text { veloped and well-nourished child. }\end{array}$ \\
\hline 4 & $\begin{array}{l}\text { Babies' } \\
5719 \\
\text { A. F. }\end{array}$ & $\sigma^{*}$ & 7 & $12 / 9 / 11$ & $\begin{array}{l}\text { Began to vomit during } 5 \text { th week; very } \\
\text { little relation to feeding, sometimes } \\
\text { immediately after, sometimes one or } \\
\text { two hours after; usually forcible. }\end{array}$ & G & 756 & $\begin{array}{l}\text { Discharged Jan. 1, 1912; weight } \dot{7} \text { lbs., } \\
14 \text { oz.; last seen March, 1914; walking: } \\
\text { condition excellent; weight } 30 \text { lbs. }\end{array}$ \\
\hline 5 & $\begin{array}{l}\text { Babies' } \\
6627 \\
\text { J. W. }\end{array}$ & $\sigma^{\prime}$ & 10 & $8 / 9 / 12$ & $\begin{array}{l}\text { Vomiting and constipation from } 3 \mathrm{~d} \text { week } \\
\text { after birth. }\end{array}$ & $?$ & $513 / 16$ & $\begin{array}{l}\text { Died } 6 \text { days after operation; necropsy } \\
\text { showed no peritonitis; wound in good } \\
\text { condition; tumor size of terminal pha- } \\
\text { lanx ring-finger and admits slate-pencil. }\end{array}$ \\
\hline 6 & $\begin{array}{l}\text { St. Luke's } \\
\text { Newburg, } \\
\text { N. Y. } \\
\text { C. T. }\end{array}$ & 5 & 7 & $7 / 8 / 12$ & $\begin{array}{l}\text { Vomiting and constipation } 6 \text { th week after } \\
\text { birth. Vomiting projectile in character. } \\
\text { Lost } 2 \text { pounds in one week. }\end{array}$ & 8 & 9 & $\begin{array}{l}\text { Discharged July 16, 1912; weight } 9 \text { lbs. } \\
5 \text { oz.; last heard from Jan. } 25,1914 \text {; } \\
\text { weight } 28 \text { pounds. }\end{array}$ \\
\hline 7 & $\begin{array}{l}\text { Babies' } \\
\text { G. L. }\end{array}$ & $\sigma^{*}$ & 3 㠳 & $12 / 12 / 12$ & $\begin{array}{l}\text { Vomiting began suddenly in } 7 \text { th week; } \\
\text { vomited after every feeding; always } \\
\text { projectile and large. }\end{array}$ & 8 & 756 & $\begin{array}{l}\text { Discharged Dec. 21, 1912; last seen } \\
\text { March, 1914, walking; weight } 26 \\
\text { pounds; } 16 \text { teeth. }\end{array}$ \\
\hline 8 & $\begin{array}{l}\text { Babies' } \\
7107 \\
\text { H. L. }\end{array}$ & 8 & 7 & $1 / 1 / 13$ & $\begin{array}{l}\text { Began to cough and vomit in } 5 \text { th week. } \\
\text { During the 6th week symptoms had be- } \\
\text { come worse, vomited after every feed } \\
\text { ing. }\end{array}$ & $\S$ & 633 & $\begin{array}{l}\text { Discharged Jan. 28, 1913; weight } 61 \mathrm{bs} \text {. } \\
111 / 2 \text { oz.; last seen March } 12,1913 \text {; } \\
\text { weight } 9 \text { lbs. 21/2 oz.; excellent con- } \\
\text { dition. }\end{array}$ \\
\hline 9 & $\begin{array}{l}\text { Babies' } \\
7127 \\
\text { T. V. }\end{array}$ & $q$ & $2 \ddagger$ & $1 / 20 / 13$ & $\begin{array}{l}\text { Typical symptoms began at } 2 d \text { week of } \\
\text { age. Nursed for } 5 \text { weeks and for past } \\
3 \text { weeks was fed patented food under } \\
\text { direction trained nurse. Admitted in } \\
\text { dying condition. Temperature too low } \\
\text { to register by thermometer until mus- } \\
\text { tard bath was given. }\end{array}$ & $10(?)$ & $511 / 16$ & $\begin{array}{l}\text { Died } 11 / 2 \text { days after operation. Necropsy: } \\
\text { Large hard tumor-admits probe-no } \\
\text { repair. }\end{array}$ \\
\hline 10 & $\begin{array}{l}\text { Babies' } \\
7228 \\
\text { P. B. }\end{array}$ & $0^{*}$ & 7 & $2 / 9 / 13$ & $\begin{array}{l}\text { In 3d week sudden onset of projectile } \\
\text { vomiting, six or seven times daily, soon } \\
\text { followed nearly every feeding. Obsti- } \\
\text { nate constipation and loss of weight. }\end{array}$ & 8 & $61 / 8$ & $\begin{array}{l}\text { Died } 9 \text { hours after operation. Necropsy: } \\
\text { Large blood clot in transverse fissure } \\
\text { of liver from falciform ligament. }\end{array}$ \\
\hline 11 & $\begin{array}{l}\text { Babies' } \\
7382 \\
\text { M. C. }\end{array}$ & $\delta$ & $61 / 2$ & $3 / 27 / 13$ & $\begin{array}{l}\text { Vomiting began suddenly in } 3 d \text { week, } \\
\text { sometimes occurtcd during feeding, but } \\
\text { most often few minutes after; always } \\
\text { a larger amount. Condition bad; given } \\
\text { mustard baths, hypodermoclysis, etc. }\end{array}$ & $71 / 81$ & $5 \% 32$ & $\begin{array}{l}\text { Died } 10 \text { hours after operation. Necropsy: } \\
\text { Anastomosis firm. Pylorus admits small } \\
\text { probe. }\end{array}$ \\
\hline 12 & $\begin{array}{l}\text { Babies' } \\
7651 \\
\text { S. G. }\end{array}$ & q & 8 & $6 / 13 / 13$ & $\begin{array}{l}\text { Spat up once or twice a day and vomited } \\
\text { occasionally before } 5 \text { weeks old. Vomits } \\
\text { at times while nursing, just afterward, } \\
\text { or within an hour. Vomiting is projec- } \\
\text { tile. Three weeks constipation. In col- } \\
\text { lapse at time of operation. }\end{array}$ & $\|$ & $65 / 16$ & $\begin{array}{l}\text { Died } 4 \text { hours after operation. Necropsy: } \\
\text { Large hard tumor. }\end{array}$ \\
\hline 13 & $\begin{array}{l}\text { Babies' } \\
7809 \\
\text { R. J. }\end{array}$ & 8 & 4 & $7 / 14 / 13$ & $\begin{array}{l}\text { Ten days before admission began vomit- } \\
\text { ing after nearly every feeding; con- } \\
\text { tinued for two or three days, then vom- } \\
\text { ited after all feedings. Vomiting al- } \\
\text { ways forcible. }\end{array}$ & $\|$ & $5^{2} 1 / 32$ & $\begin{array}{l}\text { Discharged Aug. 10, 1913; weight } 7 \text { lbs. } \\
1 \text { oz. Last seen February, 1914, weight } \\
16 \text { pounds. }\end{array}$ \\
\hline 14 & $\begin{array}{l}\text { Babies' } \\
\text { D. P. }\end{array}$ & $\delta$ & 4 & $7 / 17 / 13$ & $\begin{array}{l}\text { Vomiting began } 3 \mathrm{~d} \text { day after birth, and } \\
\text { at the end of the first week it occurred } \\
\text { during or soon after every feeding; } \\
\text { obstinate constipation. }\end{array}$ & $81 / 2$ & $61 / 8$ & $\begin{array}{l}\text { Discharged July } 31,1913 \text {. Cured, weight } \\
7 \text { Ibs. } 8 \text { oz. Died Nov. } 2,1913 \text {, of } \\
\text { laryngeal diphtheria. Condition had } \\
\text { been splendid; just before death weighed } \\
15 \text { ibs. Necropsy Tumor persists, } \\
\text { rather small and admits slate-pencil. }\end{array}$ \\
\hline 15 & $\begin{array}{l}\text { Babies' } \\
7953 \\
\text { M. G. }\end{array}$ & $d^{\pi}$ & 6 & $8 / 10 / 13$ & $\begin{array}{l}\text { Vomiting began about one week after } \\
\text { birth. Let up during 3d week; re- } \\
\text { curred and followed every feeding; } \\
\text { never projectile. }\end{array}$ & $?$ & $53_{16}^{\prime}$ & $\begin{array}{l}\text { Died } 5 \text { days after operation. Necropsy: } \\
\text { general peritonitis from leakage; no } \\
\text { effort on part of wound to heal. }\end{array}$ \\
\hline 16 & $\begin{array}{l}\text { Babies' } \\
\text { R. W. }\end{array}$ & 0 & 6 & $12 / 4 / 13$ & $\begin{array}{l}\text { Began to vomit in the } 5 \text { th week; always } \\
\text { projectile. }\end{array}$ & $\|$ & $93 / 8$ & $\begin{array}{l}\text { Discharged Dec. } 15,1913 \text {; weight } 9 \text { lbs. } \\
7 \mathrm{oz} \text { March, 1914, weighs } 13 \text { pounds. }\end{array}$ \\
\hline 17 & $\begin{array}{l}\text { St. Luke's } \\
98286 \\
\text { E. B. }\end{array}$ & 9 & 5 & $1 / 24 / 14$ & $\begin{array}{l}\text { Vomiting began in the 4th week. Did } \\
\text { not nurse well from birth; reached } \\
\text { birth-weight on 12th day, but never } \\
\text { went over it. Lost } 1 \text { lb. and } 4 \text { oz. } \\
\text { in } 6 \text { days. }\end{array}$ & $63 / 8$ & 5 & $\begin{array}{l}\text { Discharged Feb. } 23 \text {, } 1914 ; \text { weight } 6 \text { lbs. } \\
12 \text { oz.; March } 27 \text {, weight } 7 \text { lbs. } 11 \text { oz. }\end{array}$ \\
\hline 18 & $\begin{array}{l}\text { Babies' } \\
\text { W. M. }\end{array}$ & $d$ & 4 & $3 / 3 n / 14$ & $\begin{array}{l}\text { Vomiting began about } 20 \text { th day after } \\
\text { birth, gradually increasing in frequency } \\
\text { and force. Became forcible } 5 \text { days be- } \\
\text { fore admission. }\end{array}$ & $83 / 4$ & 758 & $\begin{array}{l}\text { Discharged April 8, } 1914 \text {; weight } 8 \text { lbs } \\
3 \text { oz. At present the child is in good } \\
\text { condition. }\end{array}$ \\
\hline 19 & $\begin{array}{l}\text { Babies' } \\
\text { J. W. }\end{array}$ & $\delta$ & 4 & $4 / 10 / 14$ & $\begin{array}{l}\text { Began to vomit on the 12th day (while } \\
\text { nursing) after birth. Weaned on the } \\
21 \text { st day. Improvement slight and only } \\
\text { temporary on artificial food. Marked } \\
\text { jaundice for } 4 \text { days before operation, } \\
\text { and vomiting became projectile } 4 \text { days } \\
\text { before operation. }\end{array}$ & $71 / 2$ & $6^{15} / 16$ & $\begin{array}{l}\text { Discharged April 18, 1914; Weight } 7 \text { lbs. } \\
3 \text { oz.; jaundice disappeared } 4 \text { days after } \\
\text { operation. May 10, } 8 \text { lbs. } 8 \text { oz. }\end{array}$ \\
\hline 20 & $\begin{array}{l}\text { Babies' } \\
\text { E. H. }\end{array}$ & 우 & 5 & $4 / 15 / 14$ & $\begin{array}{l}\text { before operation. } \\
\text { Up to } 2 \text { weeks of age occasional regurgi- } \\
\text { tation. At } 2 \text { weeks vomiting started } \\
\text { gradually increasing in frequency. Vom- } \\
\text { iting became projectile } 7 \text { days before } \\
\text { admission. Nursed up to present time. }\end{array}$ & $?$ & $55 / 16$ & $\begin{array}{l}\text { Discharged April 27, } 1914 \text {; weight } 5 \text { lbs. } \\
15 \text { oz. May 14, } 6 \text { lbs. } 3 \text { oz. }\end{array}$ \\
\hline 21 & $\begin{array}{l}\text { Babies' } \\
\text { T. W. }\end{array}$ & $d^{\prime \prime}$ & 7 & $4 / 16 / 14$ & $\begin{array}{l}\text { Regurgitation one to three times a day } \\
\text { started at } 4 \text { weeks old. Real vomiting } \\
\text { started at } 6 \text { weeks; three to five times } \\
\text { a day up to } 7 \text { weeks old, and then after } \\
\text { practically every feeding. Never pro- } \\
\text { jectile though slightly forcible on one }\end{array}$ & $77 / 16$ & $611 / 16$ & $\begin{array}{l}\text { Discharged April 29, 1914; gained } 11 \\
\text { ounces. }\end{array}$ \\
\hline 22 & $\begin{array}{l}\text { Babies' } \\
\text { W. S. }\end{array}$ & 8 & 6 & $4 / 23 / 14$ & $\begin{array}{l}\text { Voccasion. } \\
\text { omiting started at age of } 4 \text { weeks and } 2 \\
\text { days; once a day for } 4 \text { days and then } \\
\text { gradual y increased in frequency; } 3 \\
\text { days before operation vomited after } \\
\text { every feeding. Vomiting projectile from } \\
\text { the first and usually very large amount. }\end{array}$ & 6 & $61 / 8$ & $\begin{array}{l}\text { Discharged May } 5,1914 ; \text { gained } 8 \text { oz. } \\
\text { May 14, weight } 7 \text { ibs. } 9 \text { oz. }\end{array}$ \\
\hline
\end{tabular}

* In this column $\delta$ means boy and $q$ girl. † Days. \$Mcnths. \$ Small baby at birth. IAt onset of symptoms. \| Large baby. 
such a .way that the edges of the wound are gently drawn apart, and as the incision is deepened a definite line of cleavage will be seen to exist between the pyloric muscle and the mucous membrane. If this point is observed, injury to the mucosa is not likely to occur. Gastro-enterostomy should be the operation of choice in all cases in which the condition of the child is even fair, for the reason that it is an established surgical procedure, the results of which are certain, and the partial pyloroplasty reserved for those cases in which haste is the first consideration. The latter operation is not free from the immediate risk of injury to the mucosa, and its future is uncertain. In Case 20 the recovery of the child has been uninterrupted, but its progress has been much slower than in the other cases.

The after-care of the patients is extremely important, and much depends on the judicious use of stimulants in the form of brandy, atropin and caffein, and also the proper use of fluids by hypodermoclysis and the Murphy drip. That it is not necessary to resort to these measures in the cases which come to operation while yet in good condition is shown by the postoperative reaction and convalescence of a number of the babies in this series, the postoperative course of which reminded one much of the after-history of the average gastro-enterostomy in the adult. Feeding should be started just as soon as possible after operation; small quantities of water alternating with diluted breast-milk were given hourly, beginning as early as the second or third hour in several of our cases. The amount should be increased gradually, and if it is well borne, the child may be put back to the breast in fortyeight hours. It is important to elevate the head of the bed just as soon as reaction is well established, as this facilitates the escape of gas and greatly lessens the tendency to vomit.

A colon irrigation should be given in twenty-four hours, or sooner if there is much distention. The first fecal stool usually occurs from twenty-four to fortyeight hours after operation; if not by this time, from 1 to 2 teaspoonfuls of castor oil should be administered.

I am indebted to the Medical Service of the Babies' Hospital for the privilege of operating in twelve of the cases; the others came through various consultants. In no case have I declined to operate on account of the poor risk. I have not operated for so-called pyloric spasm without hypertrophy, nor do I believe that such patients should be operated on. Two of these patients have been seen in consultation and surgical treatment advised against. Both made good recoveries. There were seven deaths in the series, which must stand on the records as representing the operative mortality. Of the seven patients, three (Cases 9, 11 and 12) were in a collapse at the time of operation and the outcome was to be expected. Our judgment in each instance was against operating, but we had had two infants in almost the same condition (Cases 3 and 8 ), both of whom came through the operation with little or no additional shock and are to-day in perfect health. A note taken from the history of Case 3, made just prior to operation reads as follows:

Weight 5 pounds $10 \mathrm{r} / 2$ ounces; temperature 103.2 at 7 a. m., normal at 9 a. $\mathrm{m}$.; child is becoming more relaxed, shows a decided loss of tone. Strychnin sulphate, 1/450 grain, ordered every four hours and a mustard bath three times a day.
Vomiting forcible and in large amounts persists. General condition since $5 \mathrm{p}$. $\mathrm{m}$. yesterday has grown gradually but steadily worse. Pulse is not good; child looks sick about the eyes. P. M. Note: Child prostrated, in a dying condi-. tion, rallied slightly toward evening. As a last resort the baby was operated on at $10 \mathrm{p} . \mathrm{m}$.

The history of Case 8 has the following note made on the day of operation:

This forenoon the appearance of the baby did not seem quite as promising, although yesterday he took all his food except 2 ounces, and stool contained some fecal matter. To-day had one stool (4 p. m.) a dark green-brown stain. Toward evening he did not seem so lively as in the morning; cry feeble, and on the whole decidedly more asthenic. Aspiration showed $1 \mathrm{t} / 2$ ounces' retention-more than any previous aspiration. In view of the fact that the baby has little food coming through as evidenced by his stools, his progressive asthenia, non-response to feeding and inability to pass the duodenal tubes (Numbers 11, 12, 17 French), operation was decided on to-night.

Not to have operated in the three cases above referred to after such a happy outcome as resulted in Cases 3 and 8, would have been unfair.

Patient 1 died on the eleventh day after operation. This baby was given fourteen days of careful medical treatment, during which time the condition was thought to be due to pyloric spasm, as no tumor could be made out. The child became very weak and operation was decided on. Under anesthesia a large tumor could be felt at the pylorus. There was no shock. Small amounts of water were begun after seven hours. Note day after operation says, "Child looks well." The first movement occurred thirty hours after operation, and there were several movements daily from that time until death. There was no vomiting for several days and the child seemed to be on the road to recovery, but about the fifth day after operation the condition became unsatisfactory. Vomiting recurred and in spite of every possible means of relief the child grew progressively worse and died eleven days after operation. Complete necropsy failed to disclose the cause of death. The wounds had healed perfectly and there were no adhesions.

Patient 5 died six days after operation. The indications for operation seemed clear--projectile vomiting, marked loss of weight, palpable tumor, constipation, and the fact that the duodenal catheter could not be passed. The stomach was found to be intensely dilated, the walls thickened and edematous; the tumor was the size of the terminal phalanx of the middle finger. There was no shock. Three hours after operation, the patient began to vomit small amounts. Feeding was begun in ten hours; the first stool was noted thirtysix hours after operation, and during the second day there were seven stools. The patient vomited three or four times each day, the vomitus gradually becoming larger in quantity and projectile. There was no abdominal distention. The patient died on the sixth day. Necropsy showed no peritonitis, and anastomosis firm. The tumor persisted at the pylorus, but the lumen would easily admit a slate-pencil. Possibly the patency of the pylorus in this case, by allowirg food to pass through, had something to do with the continued spasmodic contraction. That food entered the intestine freely was shown by the size and quality of the stools.

Patient 10, weight 6 pounds 2 ounces, although rather feeble, stood the operation very well, with little or no shock. Small quantities of water were begun after three hours. Six hours after operation the patient's condition became critical; four hours later the baby died. Necropsy disclosed a large blood-clot in the transverse fissure of the liver, and the hemorrhage could be traced directly to a catgut suture which had been passed through the round ligament. Cause of death was postoperative hemorrhage.

Patient 15, a small baby, weight 5 pounds 3 ounces; did well for three days, but then began to show signs of peri- 
tonitis. It died on the fifth day after operation. Necropsy disclosed general peritonitis from leakage, with no effort at repair.

These two cases illustrate dangers of the operation which cannot be overestimated, and show that even though one has had some experience in this work, fatal errors in technic may and do occur.

Of the seven fatal cases, so far as we know, only one had had careful medical attention and treatment from the beginning of the symptoms; most of the patients had made an occasional visit to the doctor or dispensary and a few had been seen by specialists in consultation, whereas, of the fifteen that recovered, nine were private patients, all of whom had been treated skilfully by competent men from the onset of symptoms, and had been seen in consultation by either Drs. Holt, Kimball, Kerley or La Fetra. These cases came to operation after a reasonable time had been spent in attempting to control the symptoms by medical means; the patients were still in good condition, and as a result made practically uninterrupted recoveries. Two patients died after discharge from the hospital, from causes in no way connected with the operation. Patient 2 was discharged twelve days after operation, having gained 4 ounces and was brought back four days later with an acute gastro-enteritis from which it died. Complete necropsy showed the wound in perfect condition and the cause of death to be acute enteritis. In the other fatal case (No. 14), the patient was discharged July 31, 1913, and died Nov. 2, 1913, of laryngeal diphtheria. The condition had been splendid and just before death the baby weighed 15 pounds. Partial necropsy showed that the tumor, which was rather small, but very hard at operation, persisted.

Careful examination of the stomachs removed at necropsy from the patients dying after operation showed that the pyloric tumors were almost exactly of the same size and consistency as they had been at the operating-table, varying in size from the terminal phalanx of the ring-finger to that of the thumb and having the consistency of cartilage. They were formed entirely by the hypertrophied circular muscle-fibers of the pylorus. The mucous membrane lay in longitudinal folds in the lumen. It was much thickened and arranged in a more or less spiral manner.

In view of the experience gathered from the observation of these cases, I believe I am justified in offering the following conclusions:

1. Hypertrophic pyloric stenosis is congenital to the extent that there is an increase in the thickness of the circular muscle-fibers at the pylorus. The presence of this thickened muscle-fiber reduces the lumen of the pylorus, and therefore the stomach, in order to empty itself, contracts more forcibly than normal. This abnormal contraction soon causes the mucous membratle to become thickened and edematous, and assume a more or less spiral arrangement as it passes through the narrowed pyloric channel of from $\mathrm{r} / 2$ to $3 / 4 \mathrm{inch}$. The result is a valvular action which gradually procluces complete closure of the pylorus. The question as to whether or not the pylorus will admit a probe or catheter at operation or necropsy is of little consequence when weighed against the clinical evidence of complete obstruction.

2. That there is sufficient time between the onset of symptoms and the appearance of the signs of complete obstruction, for careful observation and the carrying out of any medical measures likely to prove of benefit, there can be no doubt, provided, of course, that the early symptoms have been properly interpreted. The fear, however, that the condition may have existed longer than has been suspected, and that the vitality of the baby is not so good as appearances would lead us to believe, makes me feel that operation is indicated in every case of hypertrophic stenosis as soon as the diagnosis is made. Should depression or early evidence of shock be -present, immediate operation is demanded.

3. The babies coming to operation in good condition suffer little or no shock; their convalescence is straightforward, and they are at once restored to normal health. $\mathrm{My}$ experience in this respect corresponds with that of other operators.

I cannot close this paper without referring to the wonderful results obtained by Drs. Scudder of Boston and Richter of Chicago in the operative treatment of pyloric stenosis. The former has recently reported a series of seventeen cases with four deaths and the latter has a record of twenty-two cases with three deaths.

37 West Seventy-First Street.

\section{AN INTERNAL ALEXANDER OPERATION *}

\section{HENRY T. BYFORD, M.D. CHICAGO}

Retroversion of the uterus may be associated with general abdominal and pelvic visceroptosis, or it may be due to impaired function of one or more of the so-called uterine supports. In the latter case there is usually a secondary impairment of function of the remaining supports which are, of course, thrown out of normal action in consequence of the abnormal position of the uterus. An operation to relieve such a deformity does not necessarily have to attack all of the overstretched or relaxed structures, for, when the equilibrium of the uterus is restored and maintained for a certain length of time, those supporting structures which are only slightly deficient or are secondarily disabled may often be depended on to resume function. In limiting myself to the discussion of this class of cases, I am assuming that there is no defect in the pelvic floor, or that such defect has been remedied.

The operation which has proved most satisfactory under these conditions is the Alexander operation. It is one of the simplest of operations, consisting merely of drawing the round ligaments out through their normal channels, the inguinal canals, until the fundus is pulled to its normal position over the empty urinary bladder, and of reattaching them so as to eliminate their apparent excess in length. The part played by these ligaments in connection with retroversion and the Alexander operation is about as follows: The round ligaments are relaxed when the bladder is empty, or nearly so, although they may be supposed to contract more or less irregularly and effectually when stimulated by the shiftings or motions of the uterus accompanying general physical exercise, forced respiration, coughing defecation, etc. As the bladder fills and pushes the fundus uteri upward, the ligaments are

* Read before the thirty-ninth meeting of the American Gynecological Society, May 19, 1914. 